\title{
Modern sedimentation in the Cabo Frio upwelling system, Southeastern Brazilian shelf
}

\author{
MICHEL M. DE MAHIQUES, MARCIA C. BÍCEGO, ILSON C.A. SILVEIRA, \\ SILVIA H.M. SOUSA, RAFAEL A. LOURENÇO and MARINA M. FUKUMOTO \\ Departamento de Oceanografia Física, Química e Geológica, Instituto Oceanográfico \\ Universidade de São Paulo, Praça do Oceanográfico, 191, 05508-900 São Paulo, SP, Brasil
}

Manuscript received on May 6, 2004; accepted for publication on January 15, 2005; presented by KenitiRo Suguio

\begin{abstract}
The analyses of $U_{37}^{k^{\prime}}$ paleotemperatures and sedimentological parameters in box cores from the Cabo Frio upwelling zone, southeastern Brazil, were used to understand the modern sedimentation as well as to evaluate the role played by the upwelling process in the sedimentary patterns.

Three box-cores located closer to the upwelling area show a general trend of cooling waters taking place in the last 700 years. Since the present upwelling is dependent on local and remote wind regime, a phase of dominating NE winds favors a more effective upward transport of the cold thermocline level South Atlantic Central Water towards the coast. The intensification in the upwelling regime for the last ca. 700 years can be associated with the strengthening of the NE winds off the area and a possible increase of the Brazil Current mesoscale activity.

Nevertheless, the lack of significant correlation of the paleotemperatures and most of sedimentological parameters indicate that upwelling is not the only sedimentation mechanism in the area. Also, the comparison of sedimentological parameters reveals that eventual temporal changes are superimposed by the geographical variability. Sedimentation rates vary from $0.26 \mathrm{~mm} \cdot \mathrm{yr}^{-1}$ to $0.66 \mathrm{~mm} \cdot \mathrm{yr}^{-1}$.
\end{abstract}

Key words: sedimentation, alkenones, bulk organic matter, upwelling, Brazil, South Atlantic.

\section{INTRODUCTION}

Upwelling zones and other high sedimentation rate regions are considered key areas for the comprehension of Quaternary climatic changes. Because of this, the eastern South Atlantic tropical and subtropical margins have been studied much more than its western counterparts (Cohen and Tyson 1995, Ternois et al. 2000, DeMenocal et al. 2000, Sicre et al. 2001). The western tropical South Atlantic margin is characterized by the oligotrophic wa-

Correspondence to: Michel M. de Mahiques

E-mail: mahiques@usp.br ters of the Brazil Current (BC) and the North Brazil Current (NBC), as well as by a relative scarcity of fluvial terrigenous input, leading to a general scenario of very low sedimentation rates.

The Cabo Frio upwelling zone seems to be one of the exceptions to this pattern. Descriptive studies of this coastal upwelling process have been reported in the literature since the South Atlantic Meteor Expedition, during the 1920s (Böhnecke 1936, Emilsson 1959, 1961, Silva and Rodrigues 1966, Ikeda et al. 1974, Miranda and Castro 1979). More recent studies have approached the dynamics of the 


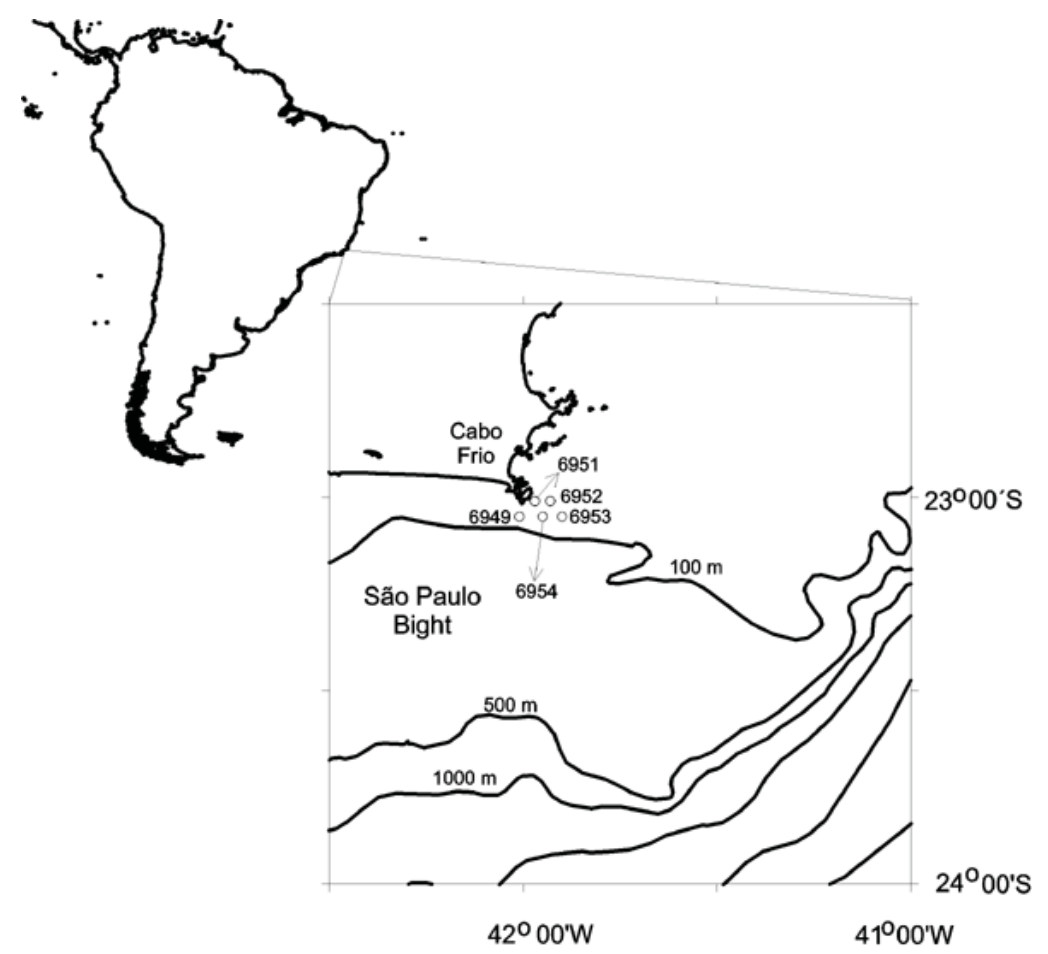

Fig. 1 - Location of the study area.

upwelling process and did not deal only with the Ekman wind-driven phenomenon but also with the supporting role played by the $\mathrm{BC}$ meandering (Lorenzzetti and Gaeta 1996, Castro and Miranda 1998, Campos et al. 2000). The consequences of the coastal upwelling in the local primary productivity have also been investigated (Valentin 1984a,b).

The aim of this paper is to understand the modern sedimentation in the Cabo Frio upwelling area as well as to evaluate the role played by the upwelling process in the sedimentary patterns. Also, the analysis of the shallow sedimentary column has been used to evaluate the occurrence of changes in the upwelling process during the last centuries.

\section{STUDY AREA}

The Cabo Frio region represents a conspicuous break in coastline orientation in the South American shoreline and marks the limit between two distinct oceanographic, physiographic and sedimentary provinces of the southwestern Atlantic Margin (Figure 1).
North of Cabo Frio, the continental margin is narrow with a dominating north-south orientation and predominant carbonate sedimentation, with few rivers to account for the local terrigenous supply. The warm and salty Tropical Water (TW) transported by the $\mathrm{BC}$ at surface levels is what maintains the carbonate production and preservation. South of Cabo Frio, the margin is wide and characterized by an arc-shaped feature known as the São Paulo Bight (Zembruscki 1979) and sedimentation is mainly terrigenous. Wind-driven circulation acting on the inner portions of the shelf and the BC meandering on the outer shelf are the most important hydrodynamic factors that determine the sedimentation in the area (Mahiques et al. 2002).

\section{THE PRESENT CABO FRIO COASTAL UPWELLING DOWNWELLING PROCESS}

The modern coastal upwelling-downwelling process is presented in the literature as a quasi-seasonal phenomenon. The coastline orientation change around $23^{\circ} \mathrm{S}$ aligns the Cabo Frio margin to the direction 


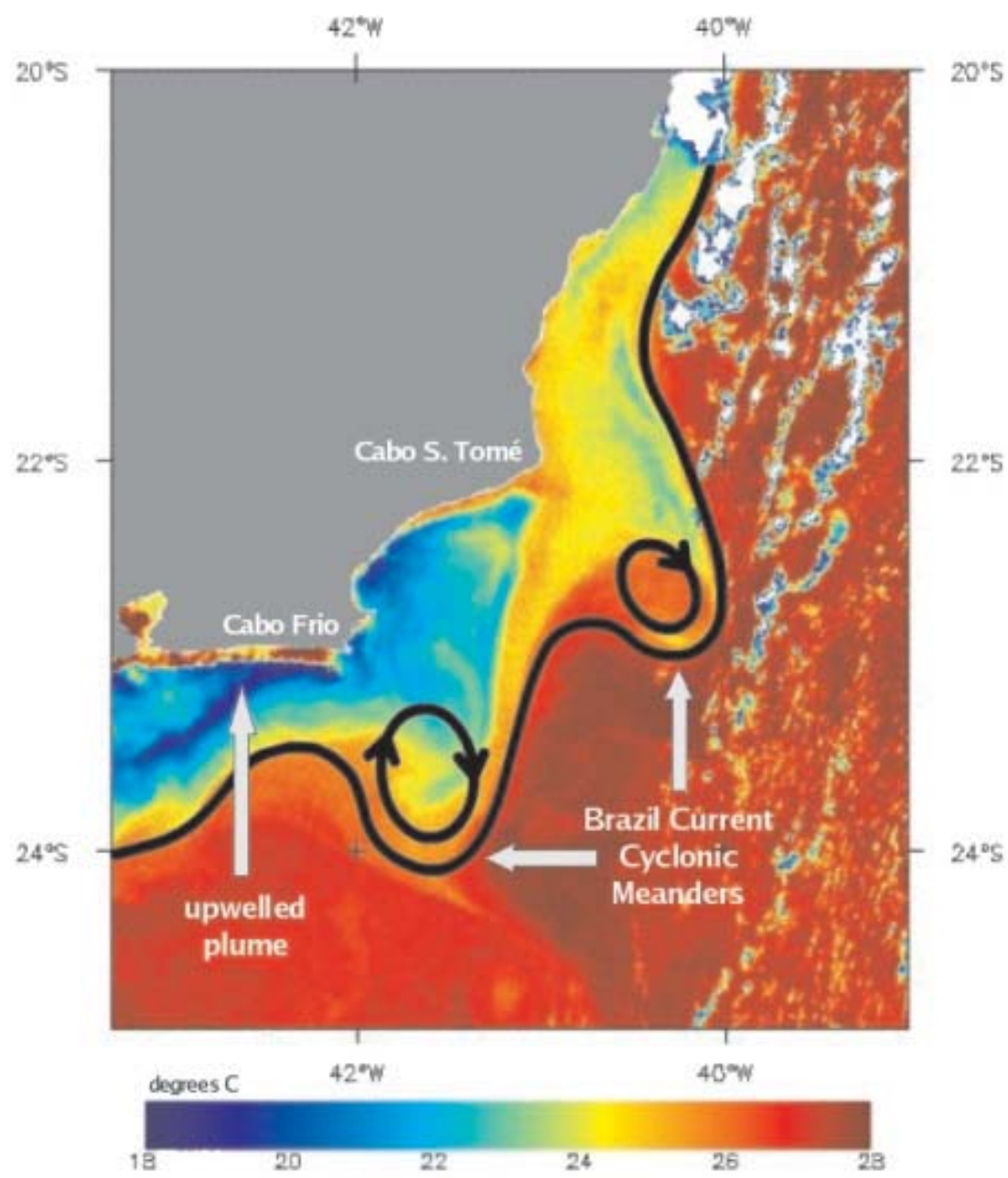

Fig. 2 - AVHRR image showing the coastal upwelling system off Cabo Frio and the Brazil Current meandering. Image provided by J.A. Lorenzzetti (INPE, Brazil).

of the dominant NE trade winds during the austral summer season. According to Ekman dynamics, the combination of these factors yields Coastal Water $(\mathrm{CW})$ to be displaced oceanward as well as TW to be prevented from penetrating the shelf. Consequently, the cold waters of the South Atlantic Central Water (SACW), which occupy the thermocline region of the water column in the open ocean area, enter the inner shelf close to the ocean bottom, and eventually upwell to surface near the coast. The more constant in direction the wind is in time, the more effective and intense is the phenomenon. As sea level lowers near the coast and thermocline rises as response to $\mathrm{CW}$ offshore motion, the generated pressure gradient drives a geostrophically balanced alongshore-coastal current that carries the upwelled waters toward southern portions of the São Paulo Bight. Its signature is easily depicted in AVHRR images (Figure 2).

The downwelling phase is associated to the passage of cold fronts through the area, most common during the austral winter season. The wind then reverses from NE to SW. The surface Ekman transport is toward the coast and composed of TW and the oceanic thermocline retracts toward the open ocean.

A recent experiment by Silveira et al. (2002) that consisted of a daily sampling of a hydrographic transect normal to the Cabo Frio Island, allowed a more precise description of both coastal upwelling 
and downwelling phases. During the austral summer of 2001, the authors identified upwelling of $13^{\circ} \mathrm{C}-14^{\circ} \mathrm{C}$ isotherms at a vertical speed ranging from 2.8 to $3.2 \times 10^{-4} \mathrm{~m} \mathrm{~s}^{-1}$. During the austral winter of 2001, the quasi-synoptic temperature and salinity distribution time series captured two events of displacement of TW domes toward the coast. They were characterized by a subsurface maximum temperature core exceeding $20^{\circ} \mathrm{C}$, and a corresponding salinity core higher than 37 . These domes represented the signature of the downwelling and were linked to a cold front motion into the area.

As both phases are linked to the inshore-offshore motion of oceanic water masses transported by the BC (i.e., TW and SACW), Campos et al. (2000) raised the hypothesis of the current cyclonic meandering enhancing the coastal upwelling. The cold core of these meanders would raise the thermocline near the slope and facilitate the penetration of SACW. As exemplified in Figure 2, there seems to be a strong link between well-developed cyclonic meanders in the area and a more robust upwelling process under favorable wind conditions.

\section{MATERIALS AND METHODS}

\section{SAMPLING}

Five box cores were collected during two cruises of the R.V. Prof. W. Besnard (Figure 1, Table I). The cores were sub-sampled continuously at intervals of $2 \mathrm{~cm}$ and the sub-samples were immediately frozen and later freeze-dried.

\section{Radiocarbon Dating and Age Model}

Due to the lack of sufficient well-preserved carbonate material it was decided to use the organic fraction of the sediment for AMS ${ }^{14} \mathrm{C}$ dating. Calibrated ages were obtained with the Calib Software (Stuiver et al. 1998), using the SW Atlantic average reservoir correction for marine samples $(\Delta=82.00$, $\mathrm{U}=46.00$ ).

The age model and the average sedimentation rates were established with the aid of the DepAge software, developed by Louis Maher Jr., from the
USGS. Calibrated ages (in yr. B.P.), and sedimentation rates (in $\mathrm{mm} . \mathrm{yr}^{-1}$ ) are presented in Table I.

\section{Alkenone Analysis}

About $15 \mathrm{~g}$ of freeze-dried sediment samples were extracted in an ultrasonic bath using successively $15 \mathrm{ml}$ of ethanol, $10 \mathrm{ml}$ of ethanol: methylene chloride (1:1) and $10 \mathrm{ml}$ of $\mathrm{n}$-hexane. The extracts were treated with $3 \mathrm{ml} 6 \%$ potassium hydroxide in ethanol for the elimination of wax ester interferences. Compounds were recovered in n-hexane and the extract was submitted to an adsorption chromatographic column with $2 \mathrm{~g}$ of a $95 \%$ activated silica gel and eluted with $12 \mathrm{ml}$ of a mixture of n-hexane: methylene chloride (8:2). This fraction was concentrated to $250 \mu \mathrm{l}$ and injected in a gas chromatograph (GC).

The analyses were performed with an Agilent GC model 6890 equipped with an on-column injector, a flame ionization detector and an Ultra-2 capillary fused silica column coated with 5\% diphenyl/ dimethylsiloxane, 0.32 of internal diameter, film thickness of $0.17 \mu \mathrm{m}$. Hydrogen was used as carrier gas. The oven temperature was programmed from $40^{\circ} \mathrm{C}$, holding for 2 minutes, $40-60^{\circ} \mathrm{C}$ at $20^{\circ} \mathrm{C} / \mathrm{min}$, then to $250^{\circ} \mathrm{C}$ at $5^{\circ} \mathrm{C} / \mathrm{min}$, and finally to $320^{\circ} \mathrm{C}$ at $6^{\circ} \mathrm{C} / \mathrm{min}$ holding for 20 minutes.

The identification of the alkenones was based on the retention time obtained from a standard mixture. The quantification was made using n-hexatriacontane as internal standard. The QA/QC was made analyzing sediment samples provided by the Autonomous University of Barcelona (Spain) for an intercomparison exercise for alkenone analysis. Our results were compared to the published data from Rosell-Melé et al. (2001) and were within the range proposed.

Alkenone-based water temperature $\left(\mathrm{U}_{37}^{k^{\prime}}\right)$ was calculated according the equation proposed by Müller et al. (1998) for the global ocean from $60^{\circ} \mathrm{N}$ to $60^{\circ} \mathrm{S}$ and confirmed by Benthien and Müller (2000) for the surface sediments of the SW Atlantic. 
TABLE I

Location, radiocarbon ages and average and sedimentation rates of the box-cores.

\begin{tabular}{c|c|c|c|c|c|c|c|c}
\hline Sample & Latitude & Longitude & $\begin{array}{c}\text { Sampling } \\
\text { depth } \\
(\mathrm{cm})\end{array}$ & Beta No. & $\begin{array}{c}\text { Conventional } \\
\text { 14C Age } \\
\text { (yr B.P. })\end{array}$ & Error & $\begin{array}{c}\text { Calibrated } \\
\text { 14C Age } \\
\text { (yr B.P.) }\end{array}$ & $\begin{array}{c}\text { Avg. Sed. } \\
\text { Rate } \\
(\mathrm{mm} / \mathrm{yr})\end{array}$ \\
\hline 6949 & $23^{\circ} 03.0^{\prime} \mathrm{S}$ & $042^{\circ} 00.6^{\prime} \mathrm{W}$ & $04-06$ & 165998 & 630 & 40 & 230 & \\
\hline 6949 & & & $12-14$ & 165999 & 880 & 40 & 450 & 0.51 \\
\hline 6949 & & & $24-26$ & 166000 & 1130 & 40 & 630 & \\
\hline 6951 & $23^{\circ} 00.6^{\prime} \mathrm{S}$ & $041^{\circ} 58.2^{\prime} \mathrm{W}$ & $04-06$ & 166004 & 550 & 40 & 60 & \\
\hline 6951 & & & $06-08$ & 166978 & 570 & 40 & 100 & 0.26 \\
\hline 6951 & & & $12-14$ & 179047 & 1050 & 40 & 540 & \\
\hline 6951 & & & $20-22$ & 179048 & 1220 & 40 & 670 & \\
\hline 6952 & $23^{\circ} 00.6^{\prime} \mathrm{S}$ & $041^{\circ} 55.8^{\prime} \mathrm{W}$ & $04-06$ & 166007 & 590 & 40 & 130 & \\
\hline 6952 & & & $08-10$ & 179049 & 810 & 40 & 380 & 0.38 \\
\hline 6952 & & & $22-24$ & 179050 & 1180 & 50 & 650 & \\
\hline 6953 & $23^{\circ} 03.0^{\prime} \mathrm{S}$ & $041^{\circ} 54.0^{\prime} \mathrm{W}$ & $04-06$ & 166979 & 690 & 40 & 270 & \\
\hline 6953 & & & $12-14$ & 166980 & 760 & 40 & 300 & 0.57 \\
\hline 6953 & & & $26-27$ & 166010 & 1130 & 40 & 630 & \\
\hline 6954 & $23^{\circ} 03.0^{\prime} \mathrm{S}$ & $041^{\circ} 57.0^{\prime} \mathrm{W}$ & $04-06$ & 166981 & 670 & 40 & 260 & \\
\hline 6954 & & & $12-14$ & 166982 & 790 & 40 & 320 & 0.66 \\
\hline 6954 & & & $28-30$ & 166011 & 1100 & 40 & 610 & \\
\hline
\end{tabular}

\section{Grain-size and Calcium Carbonate}

\section{CONTEnt Analyses}

Grain size was determined with a Malvern 2000 Laser Analyzer. Calcium carbonate was determined by weight difference prior to and after the acidification of each sample with $1 \mathrm{~N} \mathrm{HCl}$.

\section{Bulk Organic Matter Analyses}

Organic carbon, total nitrogen, and total sulfur were determined with a LECO CNS200 Analyzer after the total elimination of the calcium carbonate of the samples with $1 \mathrm{~N} \mathrm{HCl}$.

$\delta^{13} \mathrm{C}$ (reported in \%० PDB) and $\delta^{15} \mathrm{~N}$ (reported in \%० Air) analyses were performed with a VGSIRA 10 Mass Spectrometer at the Coastal Science Laboratories (Austin, TX, USA).

\section{Statistical Procedures}

Due to the small number of samples for each boxcore we applied a non-parametric Kendall- $\tau$ for identification of correlation among the parameters. For the comparison among the cores we have used the non-parametric Friedman Analysis of Variance. Significant values were considered for $\alpha \Leftarrow 0.100$.

\section{RESULTS AND DISCUSSION}

The variations of sedimentological and geochemical parameters along box cores are shown in Figures 3 to 7. Results from coretops in the upwelling zone show values of organic carbon ranging from 0.76 to $1.73 \%$, total nitrogen varies from 0.06 to $0.19 \%$, $\delta^{13} \mathrm{C}$ ranges from -20.90 to $-21.30 \%$, and $\delta^{15} \mathrm{~N}$ from 6.60 to $6.90 \%$.

Sedimentation rates varied from $0.26 \mathrm{~mm} . \mathrm{yr}^{-1}$ obtained for core 6951 to $0.66 \mathrm{~mm} . \mathrm{yr}^{-1}$ obtained for core 6954. Cores 6949, 6952, and 6953 exhibit sedimentation rates of $0.38,0.51$, and $0.57 \mathrm{~mm} . \mathrm{yr}^{-1}$, respectively (Table I).

In box-cores 6949, 6951, and 6954, located closer to the upwelling zone a statistically significant trend of upward decreasing values of sea-surface 


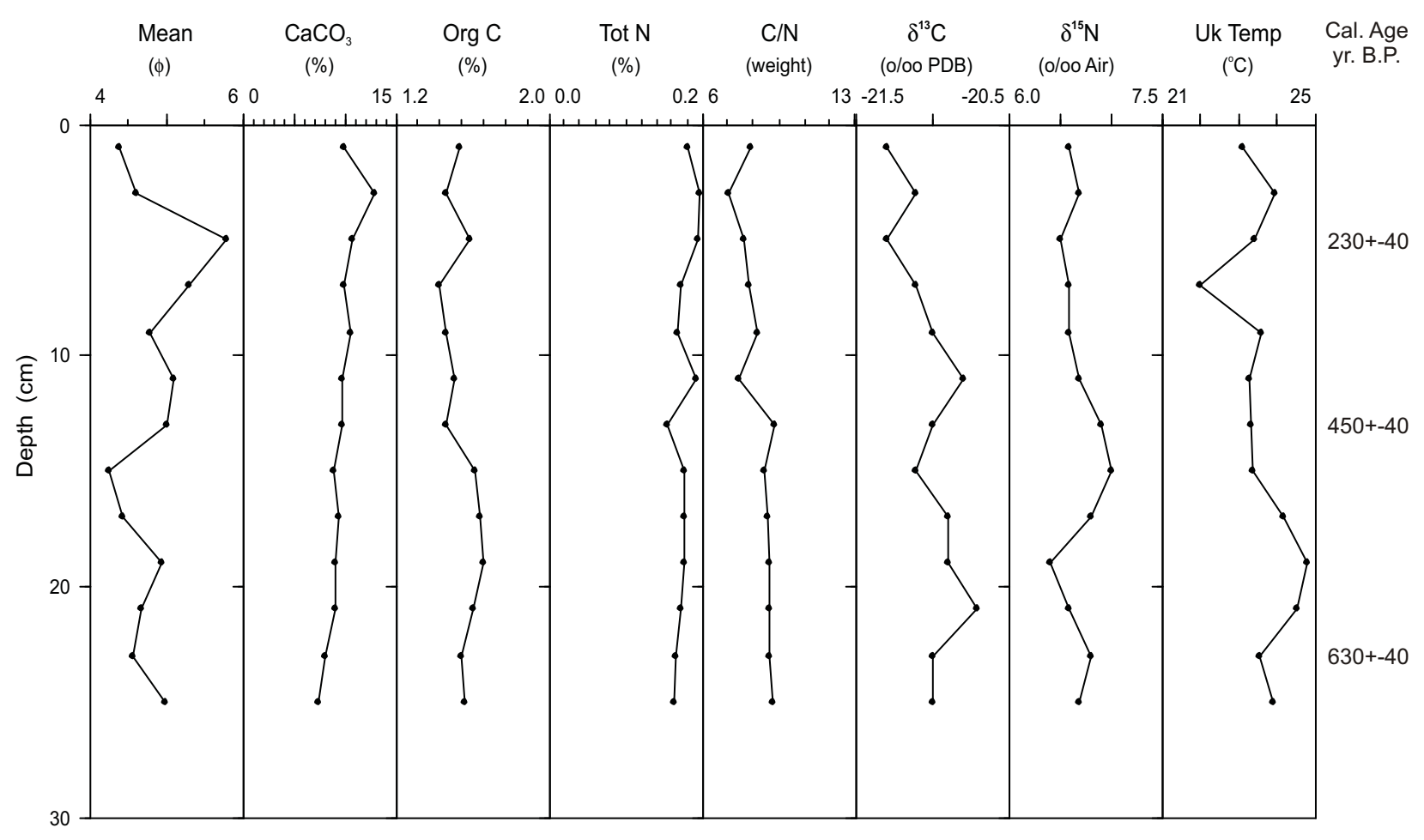

6949

Fig. 3 - Mean grain-size, compositional, isotopic, and paleotemperature variations along core 6949.

temperatures, is observed (Table II). A decreasing trend of total sulfur was observed in all of the cores and an increasing trend of calcium carbonate was observed in cores 6949, 6953, and 6954. Significant trends of the other sedimentological parameters, when observed in one or two cores, were not considered.

The significant negative correlations between $\mathrm{C} / \mathrm{N}$ ratio and organic carbon and total nitrogen, as observed in the cores, must be critically evaluated since high $\mathrm{C} / \mathrm{N}$ values can result from low organic matter content of the sediment (Nitrogen values close to the detection limit). This is particularly valid in the cases where $\delta^{13} \mathrm{C}$ values do not show significant correlations with the organic carbon content, which weakens the hypothesis of a source control on the deposition of the organic matter.

The Friedman test (Table III) revealed that with exception of the grain-size mean, all of the parameters show significant differences for at least one core, indicating that the distribution of most of the parameters is geographically dependent.

The results also show that from approximately 700 years B.P. to the present the Cabo Frio upwelling zone had a decrease in water temperature which, by its side was not followed by a response in the sedimentological parameters. The absence of significant correlation between paleotemperatures and most of the sedimentological parameters as well the geographic variability, as expressed by the sedimentation rates and sedimentological parameters of the coretops indicate that other processes such as geographical variations in the terrigenous input or the interplay between hydrodynamics and coastal and shelf morphology may also act as controllers in the sedimentary patterns of the area.

The intensification of upwelling conditions for the last 700 years can be related to a probable strengthening of the South Atlantic High Pressure, and therefore, the NE trade winds off Cabo Frio. This strengthening may dynamically have caused 


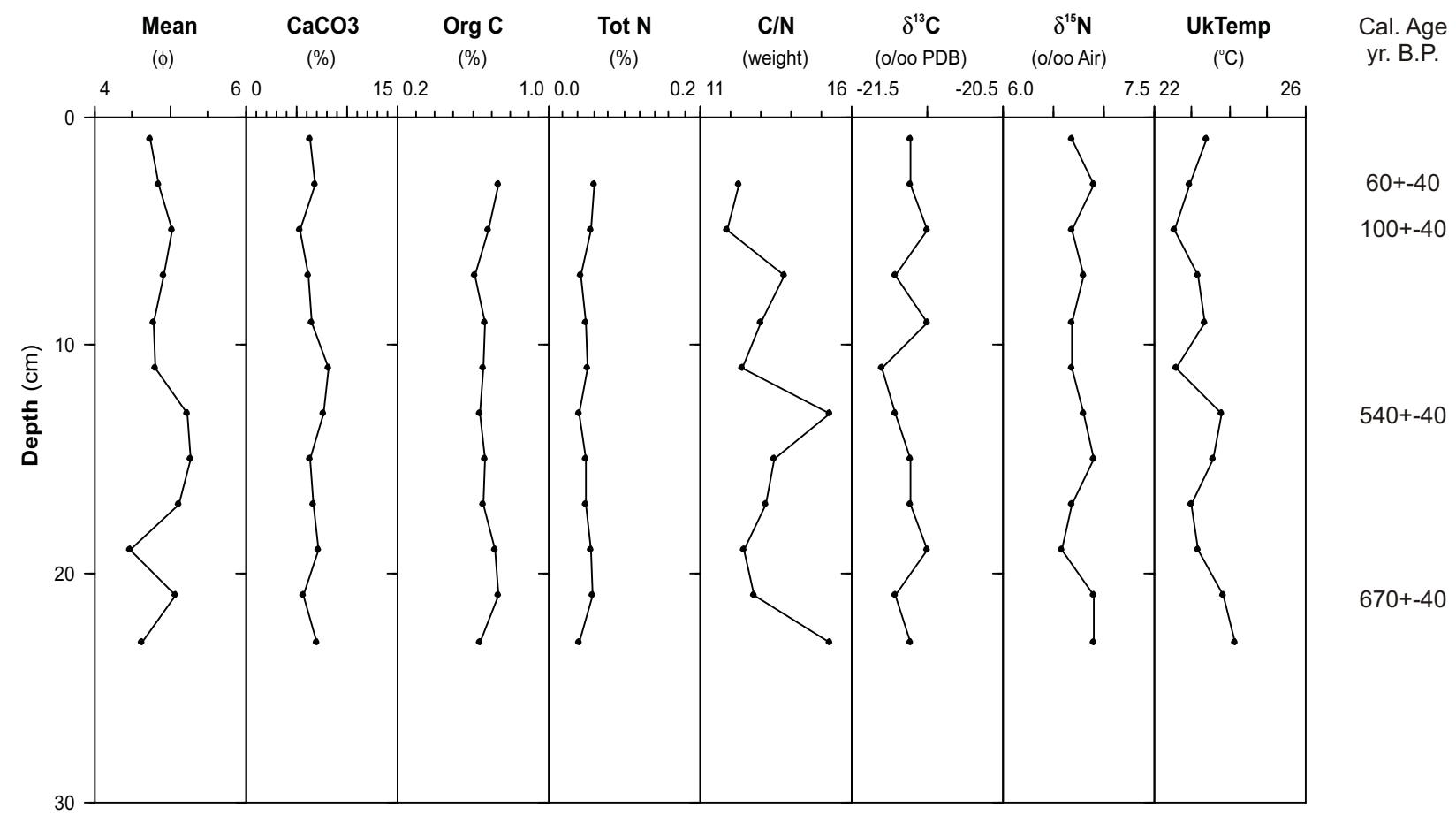

6951

Fig. 4 - Mean grain-size, compositional, isotopic, and paleotemperature variations along core 6951.

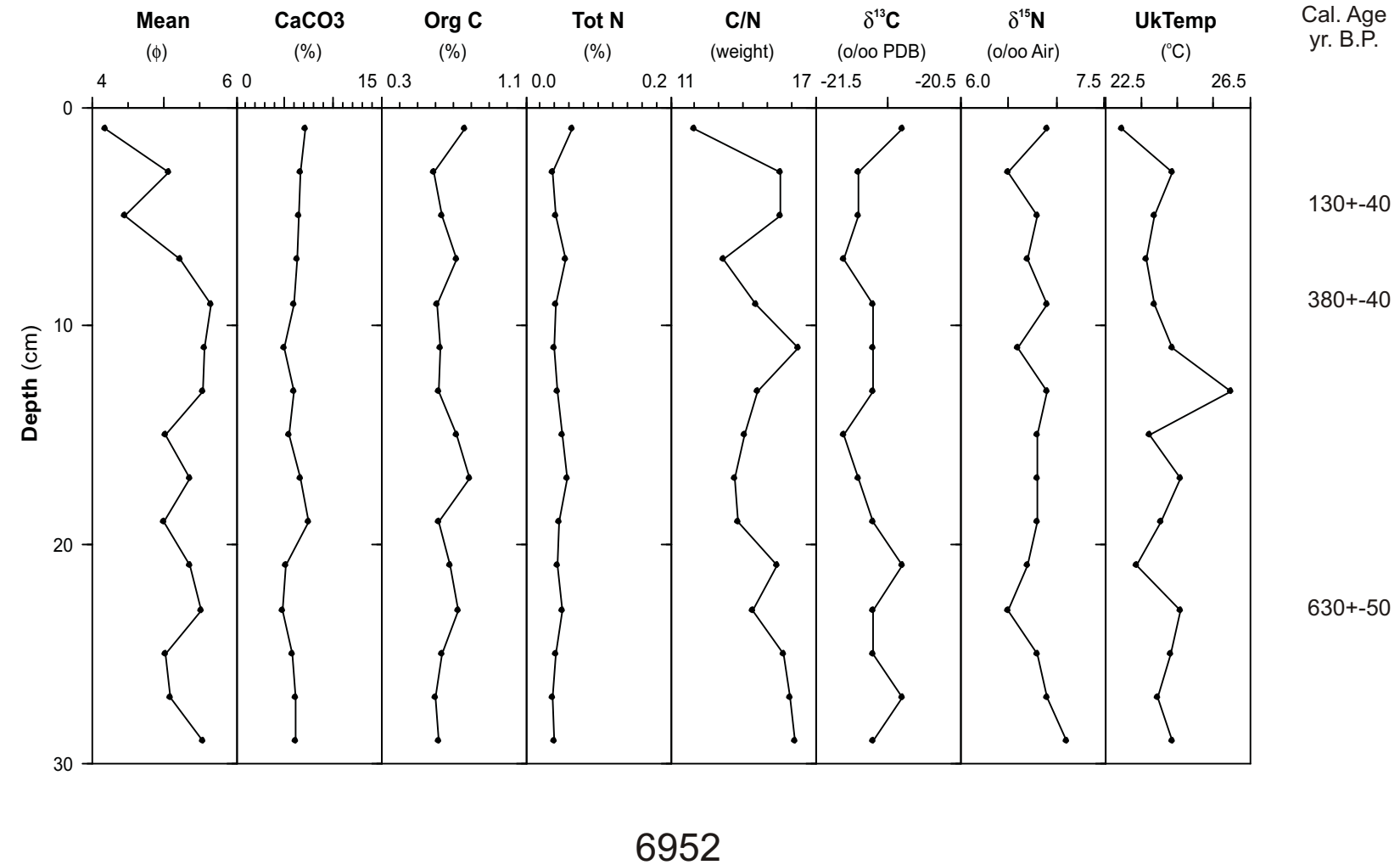

Fig. 5 - Mean grain-size, compositional, isotopic, and paleotemperature variations along core 6952. 


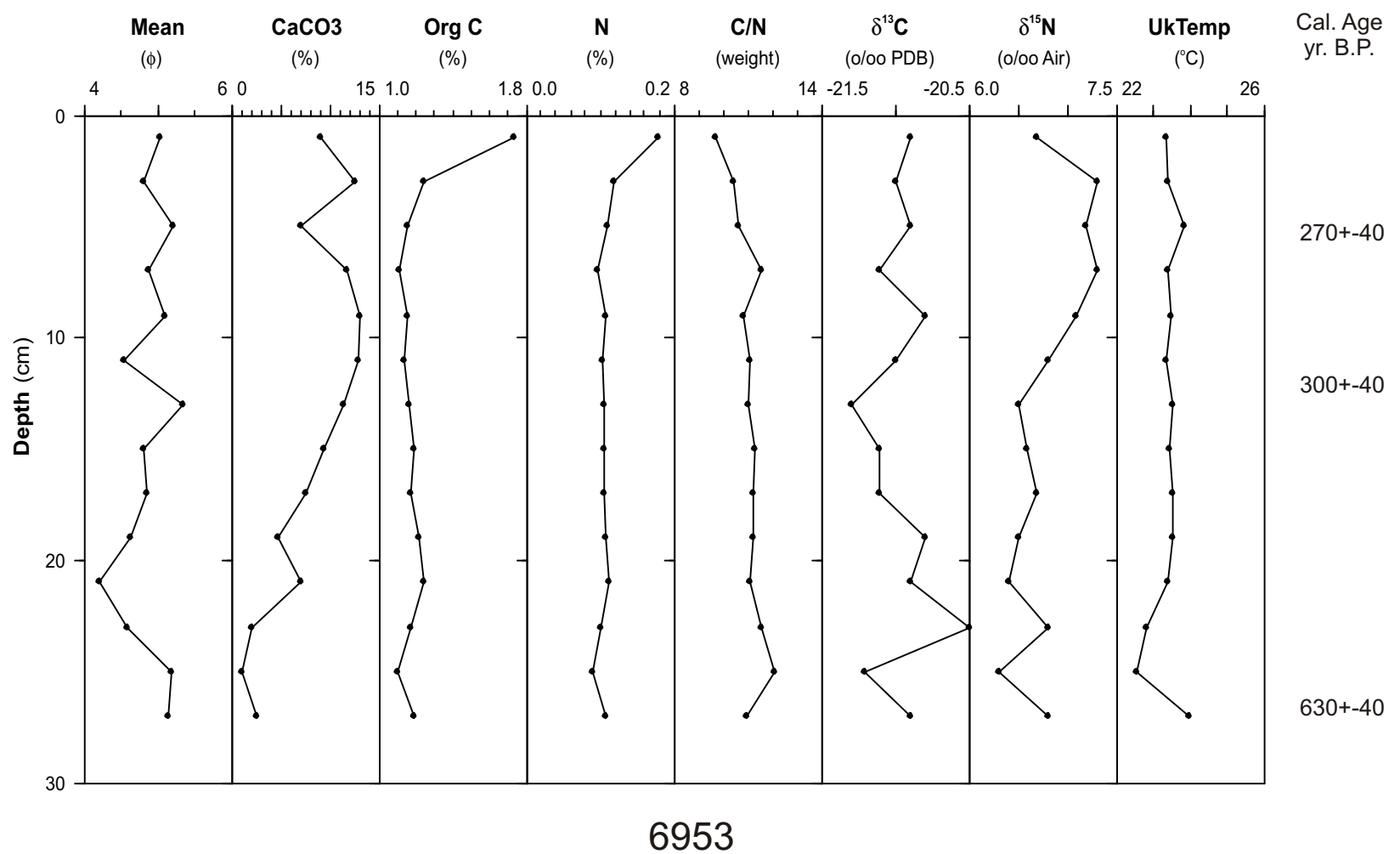

Fig. 6 - Mean grain-size, compositional, isotopic, and paleotemperature variations along core 6953.

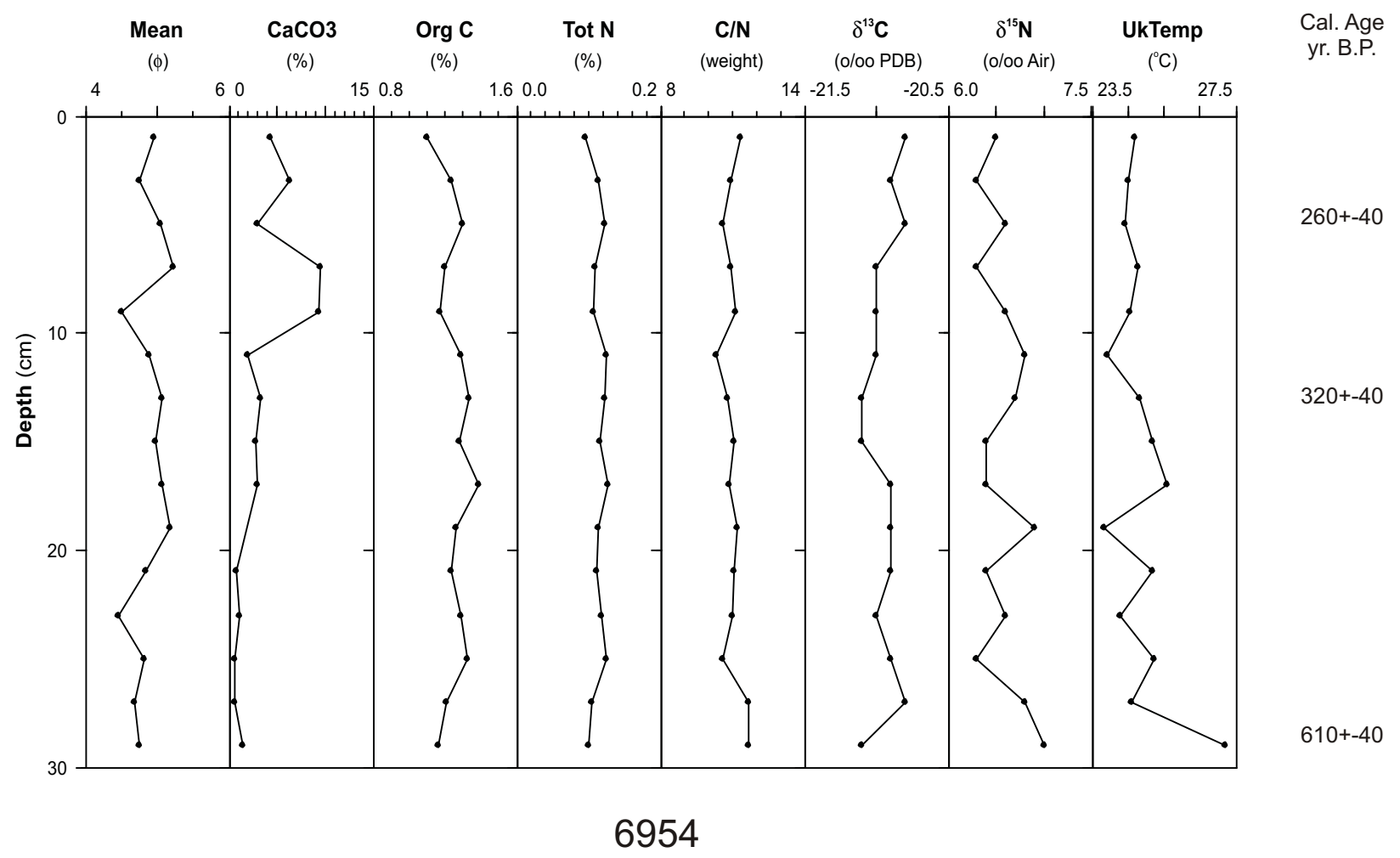

Fig. 7 - Mean grain-size, compositional, isotopic, and paleotemperature variations along core 6954. 
TABLE II

Kendall- $\tau$ correlations among the sedimentological parameters. Only significant correlations ( $\alpha \Leftarrow 0.100)$ are presented.

\begin{tabular}{|c|c|c|c|c|c|c|c|c|c|}
\hline & \multicolumn{9}{|c|}{6949} \\
\hline & Mean & Sorting & Carbonate & Carbon & Nitrogen & $\mathrm{C} / \mathrm{N}$ & $\delta^{13} \mathrm{C}$ & $\delta^{15} \mathrm{~N}$ & Uk Temp \\
\hline Depth & - & 0.38 & -0.78 & 0.35 & -0.44 & 0.61 & 0.51 & - & 0.38 \\
\hline Mean & $*$ & -0.36 & - & - & - & - & - & -0.36 & - \\
\hline Sorting & * & * & -0.40 & 0.38 & - & 0.45 & - & - & 0.44 \\
\hline Carbonate & $*$ & $*$ & $*$ & -0.37 & 0.40 & -0.57 & - & - & - \\
\hline Carbon & $*$ & $*$ & $*$ & $*$ & - & - & - & - & 0.43 \\
\hline Nitrogen & * & * & * & * & * & -0.64 & - & - & - \\
\hline Sulphur & $*$ & $*$ & $*$ & $*$ & $*$ & 0.58 & 0.55 & - & 0.40 \\
\hline $\mathrm{C} / \mathrm{N}$ & * & $*$ & $*$ & $*$ & $*$ & $*$ & - & - & - \\
\hline$\delta^{13} \mathrm{C}$ & $*$ & $*$ & $*$ & $*$ & $*$ & $*$ & $*$ & - & 0.40 \\
\hline \multirow[t]{3}{*}{$\delta^{15} \mathrm{~N}$} & $*$ & $*$ & $*$ & * & $*$ & $*$ & $*$ & $*$ & - \\
\hline & \multicolumn{9}{|c|}{6951} \\
\hline & Mean & Sorting & Carbonate & Carbon & Nitrogen & $\mathrm{C} / \mathrm{N}$ & $\delta^{13} \mathrm{C}$ & $\delta^{15} \mathrm{~N}$ & Uk Temp \\
\hline Depth & - & - & - & - & - & 0.41 & - & - & 0.39 \\
\hline Mean & $*$ & - & - & - & - & - & - & - & - \\
\hline Sorting & $*$ & $*$ & - & - & - & - & - & - & - \\
\hline Carbonate & $*$ & $*$ & $*$ & - & - & - & - & - & - \\
\hline Carbon & $*$ & $*$ & $*$ & $*$ & 0.83 & -0.65 & - & - & - \\
\hline Nitrogen & * & $*$ & $*$ & $*$ & $*$ & -0.83 & - & - & - \\
\hline Sulphur & $*$ & $*$ & $*$ & $*$ & $*$ & - & - & - & 0.42 \\
\hline $\mathrm{C} / \mathrm{N}$ & * & $*$ & * & * & * & $*$ & - & - & 0.47 \\
\hline$\delta^{13} \mathrm{C}$ & $*$ & $*$ & $*$ & $*$ & $*$ & $*$ & $*$ & - & - \\
\hline \multirow[t]{3}{*}{$\delta^{15} \mathrm{~N}$} & $*$ & $*$ & $*$ & $*$ & $*$ & $*$ & $*$ & $*$ & 0.44 \\
\hline & \multicolumn{9}{|c|}{6952} \\
\hline & Mean & Sorting & Carbonate & Carbon & Nitrogen & $\mathrm{C} / \mathrm{N}$ & $\delta^{13} \mathrm{C}$ & $\delta^{15} \mathrm{~N}$ & Uk Temp \\
\hline Depth & - & - & - & - & - & - & - & - & - \\
\hline Mean & $*$ & - & -0.44 & - & - & - & - & - & - \\
\hline Sorting & $*$ & $*$ & - & - & - & - & - & - & - \\
\hline Carbonate & $*$ & $*$ & $*$ & - & - & - & - & - & - \\
\hline Carbon & $*$ & $*$ & $*$ & $*$ & 0.69 & -0.42 & - & - & - \\
\hline Nitrogen & $*$ & $*$ & $*$ & $*$ & $*$ & -0.75 & - & - & - \\
\hline Sulphur & $*$ & $*$ & $*$ & $*$ & $*$ & - & 0.32 & - & - \\
\hline $\mathrm{C} / \mathrm{N}$ & $*$ & $*$ & $*$ & $*$ & $*$ & $*$ & - & - & - \\
\hline$\delta^{13} \mathrm{C}$ & $*$ & $*$ & $*$ & $*$ & $*$ & $*$ & $*$ & - & - \\
\hline$\delta^{15} \mathrm{~N}$ & $*$ & $*$ & $*$ & $*$ & $*$ & $*$ & $*$ & $*$ & - \\
\hline
\end{tabular}


TABLE II (continuation)

\begin{tabular}{|c|c|c|c|c|c|c|c|c|c|}
\hline & \multicolumn{9}{|c|}{6953} \\
\hline & Mean & Sorting & Carbonate & Carbon & Nitrogen & $\mathrm{C} / \mathrm{N}$ & $\delta^{13} \mathrm{C}$ & $\delta^{15} \mathrm{~N}$ & Uk Temp \\
\hline Depth & - & - & -0.56 & - & - & 0.51 & - & -0.47 & - \\
\hline Mean & $*$ & -0.54 & - & - & - & - & - & - & - \\
\hline Sorting & $*$ & $*$ & - & - & - & - & - & - & - \\
\hline Carbonate & $*$ & $*$ & $*$ & - & - & - & - & - & - \\
\hline Carbon & $*$ & $*$ & $*$ & $*$ & 0.66 & -0.35 & - & - & - \\
\hline Nitrogen & $*$ & $*$ & $*$ & $*$ & $*$ & -0.72 & - & - & - \\
\hline Sulphur & $*$ & $*$ & $*$ & $*$ & $*$ & - & - & -0.49 & - \\
\hline $\mathrm{C} / \mathrm{N}$ & $*$ & $*$ & $*$ & $*$ & $*$ & $*$ & - & - & - \\
\hline$\delta^{13} \mathrm{C}$ & $*$ & $*$ & $*$ & $*$ & $*$ & $*$ & $*$ & - & - \\
\hline \multirow[t]{3}{*}{$\delta^{15} \mathrm{~N}$} & $*$ & $*$ & $*$ & $*$ & $*$ & $*$ & $*$ & $*$ & - \\
\hline & \multicolumn{9}{|c|}{6954} \\
\hline & Mean & Sorting & Carbonate & Carbon & Nitrogen & $\mathrm{C} / \mathrm{N}$ & $\delta^{13} \mathrm{C}$ & $\delta^{15} \mathrm{~N}$ & Uk Temp \\
\hline Depth & - & - & -0.61 & - & - & - & - & - & 0.37 \\
\hline Mean & $*$ & - & 0.32 & - & - & - & - & - & - \\
\hline Sorting & $*$ & $*$ & - & - & - & - & 0.35 & - & - \\
\hline Carbonate & $*$ & $*$ & $*$ & - & - & - & - & - & - \\
\hline Carbon & $*$ & $*$ & $*$ & $*$ & 0.86 & -0.53 & - & - & - \\
\hline Nitrogen & $*$ & $*$ & $*$ & $*$ & $*$ & -0.68 & - & - & - \\
\hline Sulphur & $*$ & $*$ & $*$ & $*$ & $*$ & - & - & - & - \\
\hline $\mathrm{C} / \mathrm{N}$ & $*$ & $*$ & $*$ & $*$ & $*$ & $*$ & - & - & - \\
\hline$\delta^{13} \mathrm{C}$ & $*$ & $*$ & $*$ & $*$ & $*$ & $*$ & $*$ & - & - \\
\hline$\delta^{15} \mathrm{~N}$ & $*$ & $*$ & $*$ & $*$ & $*$ & $*$ & $*$ & $*$ & - \\
\hline
\end{tabular}

TABLE III

Friedman Analysis of Variance among the cores.

Significant values $(\alpha \Leftarrow 0.100)$ are underlined.

\begin{tabular}{c|c|c}
\hline Parameter & Friedman ANOVA & $\mathrm{p}$ \\
\hline Mean & 7.65 & 0.10536 \\
\hline Calcium Carbonate & 32.95 & 0.00000 \\
\hline Organic Carbon & 40.65 & 0.00000 \\
\hline Total Nitrogen & 40.65 & 0.00000 \\
\hline $\mathrm{C} / \mathrm{N}$ ratio & 40.90 & 0.00000 \\
\hline$\delta^{13} \mathrm{C}$ & 20.21 & 0.00046 \\
\hline$\delta^{15} \mathrm{~N}$ & 8.35 & 0.07971 \\
\hline Temperature & 20.58 & 0.00038 \\
\hline
\end{tabular}


an intensification of the Brazil Current transport and its accompanying mesoscale activity. Both stronger and persistent $\mathrm{NE}$ winds and $\mathrm{BC}$ meandering may have acted in combination to enhance the upwelling process.

Considering the morpho-tectonic framework, the Holocene sea-level changes curves available for the southeastern Brazilian coast, and the extension of the Holocene emerged deposits (Martin et al. 1997), it may be assumed that the potential conditions of coastline configuration for the occurrence of upwelling in the Cabo Frio area have been present at least since the maximum of the Holocene, represented by the Santos Transgression (Suguio and Martin 1978) which occurred 5,100 years B.P.

Important climatic changes have already been observed in the Late Holocene in South America. Veit (1996) observed the occurrence of a higher climatic variability in the subtropical region of Chile $\left(27-33^{\circ} \mathrm{S}\right)$ over the last 3,000 years, associating it with disturbances in the circulation of the westerly wind. Changes in the relative humidity conditions in $\mathrm{S}$ and SE Brazil have been related by Behling (1995, 1997) and Behling et al. (2001) to a more humid phase beginning after 1000 years B.P. Also Ybert et al. (2003) recognized alternating phases of humidity in the Southeastern Brazilian coast for the last 5,000 years but no evidence of climatic changes for the last millennium has been recognized.

Conditions for long-term changes in the dynamic regime responsible for depositional changes seem to have occurred throughout the Holocene on the eastern coast of Brazil, as shown by several authors who have dealt with the development of beach ridges in the Paraíba do Sul (approximately 60 nautical miles northward from the Cabo Frio) and Doce coastal plains (Dominguez et al. 1983, Martin et al. 1984 a,b, 1985).

Furthermore, climatic changes related to the intensification of SE cold front winds in the South Atlantic have been used by Arz et al. (1998) and Behling et al. (2000) to explain paleoceanographic and paleovegetational changes in NE Brazil during the Last Glacial Maximum. Martin et al. (1993) attribute the Holocene climatic variations in South America to long-term changes in the wind dynamics in SE Brazil.

\section{CONCLUSIONS}

The alkenone-based temperatures, sedimentological and bulk organic parameter variations in boxcores were used to better understand long-term upwelling oscillations off the Cabo Frio region, Southeastern Brazil. Despite the identification of a trend of increasing upwelling conditions for the last ca. 700 years, most of the sedimentological parameters did not show significant trends for the same period.

Due to the importance of the wind regime in the present-day upwelling conditions we can assume that its oscillation is the major factor for the water temperature variability over the last centuries.

The intensification in the upwelling regime for the last ca. 700 years can be associated with the strengthening of the NE winds off the area and a possible increase of the Brazil Current mesoscale activity.

\section{ACKNOWLEDGMENTS}

This work was funded by the Fundação de Amparo à Pesquisa do Estado de São Paulo (FAPESP) via grant nos. 00/12608-3 and 01/01098-7 and Programa de Núcleos de Excelência do Conselho Nacional de Desenvolvimento Científico e Tecnológico (PRONEX-CNPq) via grant 466031/01-7.

The authors are grateful to Dr Antoni RosellMelé from the Centre of Environmental Studies of the Autonomous University of Barcelona, for providing samples for alkenone analysis as well as to Dr Margaret Sparrow from the College of Oceanic and Atmospheric Sciences at the Oregon State University for providing the standard mixtures. Thanks also to Dr. Paula Reimer (Queen's University of Belfast, United Kingdom), for the useful information about calibration of organic carbon samples, to Dr. Jean-Claude Faugères (Université Bordeaux I, France) and Dr. Simon Troelstra (Free University, 
The Netherlands) for the critical reading and suggestions.

Thanks to Mrs. Samara Cazzoli y Goya, Mr. Marcelo Rodrigues and Mr. Edilson Faria for the grain-size, calcium carbonate and organic matter components. Thanks to Dr. Yasunobu Matsuura (in memoriam), coordinator of the Programa de Apoio ao Desenvolvimento Científico e Tecnológico Conselho Nacional de Desenvolvimento Científico e Tecnológico/Instituto Oceanográfico da Universidade de São Paulo (PADCT-CNPq/IOUSP) Project in which the samples were collected. Thanks to the crew of the R.V. Prof. W. Besnard.

This paper is a contribution to the Universidade de São Paulo (Brazil) - Université Bordeaux I (France) Cooperation Programme in Oceanography as well as to the International Geological Correlation Programme (IGCP) Number 464 Project Continental Shelves during the Last Glacial Cycle.

\section{RESUMO}

As análises de $\mathrm{U}_{37}^{k^{\prime}}$ paleotemperaturas e de parâmetros sedimentológicos em amostras de box-core da zona de ressurgência de Cabo Frio, sudeste do Brasil, foram usadas para compreender os processos de sedimentação moderna na área, bem como avaliar o papel desempenhado pela ressurgência no estabelecimento dos padrões sedimentológicos principais.

Como observado em três box-cores localizados nas proximidades da área de ressurgência, é possível verificar uma tendência geral de resfriamento das águas nos últimos 700 anos (idade calibrada). Uma vez que o processo de ressurgência é dependente do regime de ventos local e remoto, uma fase de ventos predominantes de NE favorece um deslocamento mais efetivo das águas frias da Água Central do Atlântico Sul em direção à costa.

Por outro lado, a falta de correlação significativa entre as paleotemperaturas e a maioria dos parâmetros sedimentológicos indica que a ressurgência não é o mecanismo prevalente na sedimentação da área. Além disso, a comparação dos parâmetros sedimentológicos entre os testemunhos revela que eventuais variações temporais são superimpostas pela variabilidade geográfica.

As taxas de sedimentação variam de $0,26 \mathrm{~mm} \cdot \mathrm{ano}^{-1}$ a $0,66 \mathrm{~mm} \cdot \mathrm{ano}^{-1}$.
Palavras-chave: sedimentação, alquenonas, matéria orgânica total, ressurgência, Brasil, Atlântico Sul.

\section{REFERENCES}

Arz HW, PÄtzold J AND Wefer G. 1998. Correlated millennial-scale changes in surface hydrography and terrigenous sediment yield inferred from last-glacial marine deposits of northeastern Brazil. Quaternary Res 50: 157-166.

Behling H. 1995. A high-resolution Holocene pollen record from Lago do Pires, SE Brazil - Vegetation, climate and fire history. J Paleolimnol 14: 253-268.

BEHLING H. 1997. Late Quaternary vegetation, climate and fire history from the tropical mountain region of Morro de Itapeva, SE Brazil. Palaeogeogr Palaeocl 129: 407-422.

Behling H, Arz HW, PÄtzold J and Wefer G. 2000. Late Quaternary vegetational and climate dynamics in northeastern Brazil, inferences from marine core GeoB 3104-1. Quaternary Sci Rev 19: 981-994.

Behling H, Bauermann SG and Neves PCP. 2001. Holocene environmental changes in the São Francisco de Paula region, southern Brazil. J S Am Earth Sci 14: 631-639.

Benthien A and Müller PJ. 2000. Anomalously low temperatures caused by lateral particle and sediment transport in the Malvinas Current region, western Argentine Basin. Deep-Sea Res Pt I 47: 2369-2393.

BöHNECKE G. 1936. Temperature, salinity and density of the surface waters of the Atlantic Ocean. In: ScIENtific Results of the German Atlantic eXPediTION OF THE RESEARCH VesSEl Meteor, 1925-1927. Vol. 5. published in 1994. Washington: National Science Foundation, 172 p.

Campos EJD, Velhote D and Silveira ICA. 2000. Shelf break upwelling driven by Brazil Current cyclonic meanders. Geophysl Res Lett 27: 751-754.

Castro BM and Miranda LB. 1998. Physical Oceanography of the Western Atlantic Continental Shelf Located Between $4^{\circ} \mathrm{N}$ and $34^{\circ} \mathrm{S}$ - Coastal Segment $(4, W)$. In: RobInson AR AND BRINK KH (Eds), The Sea, J Wiley \& Sons, NY, USA 11: 209-251.

Cohen AL And Tyson PD. 1995. Sea-surface temperature-fluctuations during the Holocene off the south coast of Africa - Implications for terrestrial climate and rainfall. Holocene 5: 304-312. 
DeMenocal P, Ortiz J, GuIlderson T And SARnthein M. 2000. Coherent high- and low-latitude climate variability during the Holocene warm period. Science 288: 2198-2202.

Dominguez JML, BitTencourt ACSP AND MARTin L. 1983. O papel da deriva litorânea de sedimentos arenosos na sedimentação das planícies costeiras associadas a desembocaduras dos rios São Francisco (SE/AL), Jequitinhonha (BA), Doce (ES) e Paraíba do Sul (RJ). Rev Bras Geoc 13: 93-105.

EMILSSON I. 1959. Alguns aspectos físicos e químicos das águas marinhas brasileiras. Cienc Cult 11: 44-54.

EMILSSON I. 1961. The shelf and coastal waters off southern Brazil. Bol Inst Oceanogr, São Paulo, SP, Brazil 11: 101-112.

IKEDA Y, MirandA LB AND Rock N. 1974. Observations on stages of upwelling in the region of Cabo Frio (Brazil), as conducted by continuous surface temperature and salinity measurements. Bol Inst Oceanogr, São Paulo, SP, Brazil 23: 33-46.

Lorenzzetti JA and Gaeta SA. 1996. The Cape Frio upwelling effect over the South Brazil Bight Northern sector shelf waters: a study using AVHRR images. Int Arch Photogram Rem Sens XXXI (B7): 448-453.

Mahiques MM, Silveira ICA, Sousa SHM and RoDRIGUes M. 2002. Post-LGM sedimentation on the outer shelf - upper slope of the northernmost part of the São Paulo Bight, southeastern Brazil. Mar Geol 181: 387-400.

Martin L, Flexor JM, Kousky V and Cavalcanti IF. 1984a. Inversion du sens du transport littoral enregistrées dans les cordons littoraux de la plaine côtière du Rio Doce (Brésil). Possible liaison avec des modifications de la circulation atmosphérique. CR Acad Sci II A 298: 25-27.

Martin L, Flexor JM And Suguio K. 1984b. Enregistrement des périodes de fortes et faibles énergies à l'embouchure d'un fleuve. Le cas du Paraíba do Sul (Brésil). Implications paléoclimatiques. CR Acad Sci II A 299: 661-664.

Martin L, Suguio K, Flexor JM, Tessler MG And EICHLER BB. 1985. Roundness in Holocene sands of the Paraíba do Sul coastal plain, Rio de Janeiro, Brazil. J Coastal Res 1: 343-351.

Martin L, Fournier M, Mourguiart P, Sifeddine A, Turce B, Absy ML and FleXor JM. 1993. Southern oscillation signal in South American Palaeocli- matic data of the Last 7000 Years. Quaternary Res 39: $338-346$.

Martin L, Suguio K, Dominguez JML and Flexor JM. 1997. Geologia do Quaternário costeiro do litoral norte do Rio de Janeiro e do Espírito Santo. Belo Horizonte, MG, Brasil, CPRM, 112 p.

Miranda LB and Castro BM. 1979. Condições do movimento geostrófico das águas adjacentes a Cabo Frio (RJ). Bol Inst Oceanogr, São Paulo, SP, Brasil 28: 79-93.

Müller PJ, Kirst G, Ruhland G, von Storch I AND Rosell-Melé A. 1998. Calibration of the alkenone paleotemperature index $\mathrm{U}_{37}^{k^{\prime}}$ based on coretops from the eastern South Atlantic and the global ocean $\left(60^{\circ} \mathrm{N}-60^{\circ} \mathrm{S}\right)$. Geochim Cosmochim Ac 62: $1757-$ 1772.

Rosell-Melé A ET AL. 2001. Precision of the current methods to measure the alkenone proxy $\mathrm{U}_{37}^{k^{\prime}}$ and absolute alkenone abundance in sediments: Results of an interlaboratory comparison study. Geochem Geophy Geosy 2: Art. No. 20GC0141.

Sicre M-A, Ternois Y, Paterne M, Martinez P And Bertrand P. 2001. Climatic changes in the upwelling region off Cap Blanc, NW Africa, over the last 70 kyear: a multi-biomarker approach. Org Geochem 32: 981-990.

Silva PCM AND RodRIGUES RF. 1966. Modificações na estrutura vertical das águas sobre a borda da plataforma continental por influência do vento. $\mathrm{N} \mathrm{Tec}$ Inst Pesq Mar 35: 1-13.

Silveira ICA, Castro BM, Miranda LB, Calado L, Nonato LV and Mattos RA. 2002. Condições oceanográficas de verão e inverno ao largo de Cabo Frio durante o Projeto DEPROAS. In: SIMPósIo BRASILEIRO DE OCEANOGRAFIA, 1. Instituto Oceanográfico da Universidade de São Paulo, SP, Brasil, CDROM.

Stuiver M, Reimer PJ, Bard E, Beck EW, Burr GS, Hughen KA, Kromer B, McCormac G, VAN DER Plicht J AND Spurk M. 1998. INTCAL98 Radiocarbon Age Calibration, 24000-0 cal BP. Radiocarbon 40: 1041-1083.

Suguio K And Martin L. 1978. Quaternary marine formations of the State of São Paulo and southern Rio de Janeiro. In: InTERnational Symposium ON Coastal Evolution in the Quaternary 1, São Paulo, SP, Brazil, 55 p. 
Ternois Y, Sicre M-A And Paterne M. 2000. Climatic changes along the northwestern African continental margin over the last 30 kyrs. Geophys Res Lett 27: 133-136.

VALEntin JL. 1984a. Analyses des paramètres hydrologiques dans la remontée de Cabo Frio (Brésil). Mar Biol 82: 259-276.

VALENTIN JL. 1984b. Modeling of the vertical distribution of marine primary biomass in the Cabo Frio upwelling region. Cienc Cult 44: 178-183.

Veit H. 1996. Southern Westerlies during the Holocene deduced from geomorphological and pedological studies in the Norte Chico, Northern Chile $\left(27-33^{\circ} \mathrm{S}\right)$. Palaeogeogr Palaeocl 123: 107-119.
Ybert J-P, Bissa WM, CATharino ELM and Kutner M. 2003. Environmental and sea-level variations on the southeastern Brazilian coast during the Late Holocene with comments on prehistoric human occupation. Palaeogeogr Palaeocl 189: 11-24.

ZembruscKi SG. 1979. Geomorfologia da margem continental sul-brasileira e das bacias oceânicas adjacentes. In: Chaves HAF (Ed), Geomorfologia da margem continental brasileira e das bacias oceânicas adjacentes, Rio de Janeiro. PETROBRAS 7: 129177. 